\title{
LEACHATE COMPOSITION AND ENVIRONMENTAL RISKS FROM WASTE WOOD DUMPS.
}

\author{
Kadri Auväärt \\ Urmas Uri \\ Estonian Agricultural University /Inc. Kobras, Estonia
}

Peeter Muiste

Estonian Agricultural University, Estonia

\begin{abstract}
High concentrations of phenols can be found in leachate and stormwater of wood processing, storage and disposal sites. Although timber is a natural product, mishandling of wood waste may harm the environment.

As a common practice, wood residues were dumped in landfills in Estonia. As a national strategy, it has been decided to close all of the dumping sites. In many cases, wood residues have been used for capping of municipal dump sites. It has been suspected, that environmentally hazardous phenolic compounds may be leaching out from such landfills. Pathways for generation of natural phenolic compounds, as well as the ecologic impact of them have not been studied in Estonia.

In this paper, leachate composition from dumpsites of waste wood is studied and the hazards of phenols to the environment are discussed. In the wood waste, phenol can be found mainly in tannins, resin and lignin. Phenols in tannins are water-soluble, but phenols in resins are more soluble in organic solvents, such as ether, what is produced during decomposition of lignin. Chipping and storage of wood in the water-rich environment speeds up the leaching of phenols.

The leachate from wood waste dumps is quickly purified by natural processes in the soil. It is assumed that in most cases the natural phenols do not migrate far from the dump site or storage area. The problem may arise in case where such waste is stored near to the water body or the leach-water is repeatedly re-circulated into the deposit of waste wood.
\end{abstract}

\section{INTRODUCTION}

In connection with closing down waste wood dumping sites, a question about the possibility of leaching of ecologically hazardous phenols from the waste wood frequently 
KALMAR ECO-TECH'03

Bioremediation and Leachate Treatment

KALMAR, SWEDEN, November 25-27, 2003

came up in the summer of the year 2002 in Estonia. In case of positive answer, a question about the amount of phenols and efficiency of solutions proposed by dump closing project to guarantee the nature-friendly closing of dumping site must be answered.

In Sweden, Finland, Japan etc. until the beginning the 1970ies the bark in wood storages was one of the most important environmental problems.

The aim of the present study is to scrutinize, what is the composition of the leachate characteristic to wood storages and under what conditions the phenols emerge/ leach as well as whether the amount can be hazardous to environment.

In context of this research the storages were:

- $\log$ storages

- wood soak ponds

- waste wood dumps

- waste wood storages

The analyses of the leachate were taken from two waste wood dumping sites - Helme and Veriora. Relying on earlier accomplished researches and water samples taken from soak ponds of veneer and plywood industry, different waste wood dumping sites or wodges of waste bark as well as making chemical experiments, the influence of wood storages to environment was evaluated.

\section{CHEMICAL SOLUBILITY AND MICROBIOLOGICAL DEGRADATION OF WOOD}

In general lines the chemical composition of wood can be described as follows: $50 \%$ carbon, $43 \%$ oxygen, $6 \%$ hydrogen, $0,1 \%$ nitrogen, $0,4 \%$ ashes. All the primary components form organic compounds as cellulose, lignin, hemicellulose, extractive substances (tannins, resin, fat acids etc.).

The main components of wood are:

1) cellulose $40 \ldots 50 \%$

2) hemicellulose $25 . . .30 \%$

3) lignin $20 \ldots 30 \%$

Cellulose and hemicellulose are vegetable polysaccharides. Lignin is a polyphenolic adhesive, which basic molecule is the molecule of phenylpropane. In plants the lignin is located between the mitcells of cellulose, being interrelated with them both chemically and spatially. Nonstructure and strong relations make the lignin very resistant to microorganisms and other degradation processes that take place in soil. (Kirk, Farell 1987). In unpolar organic solvent and hot water the lignin is insoluble (Land 1985).

In the process of degradation of polyphenolic lignin, the phenol emerges as intermediate which is nerve poison. In addition to the basic component - lignin - polyphenols occur also in tannins and flavonoids, which can easily degrade by environment and thereby 
KALMAR ECO-TECH'03

Bioremediation and Leachate Treatment

KALMAR, SWEDEN, November 25-27, 2003

combine pyrogallol (tribasic phenol) and pyrocathein (dibasic phenol). Some organic solvents as ether, which arises by the degradation of lignin are able to degrade polyphenols in the resin. (Kirk s.a). Simplex phenols which have a benzene annulus and one or more $\mathrm{OH}$-groups, occur relatively rarely in plants, basically these are vegetable pigments.

There are mono-, di-, tribasic etc. phenols, depending on the number of hydroxyl groups in molecule. Because of the warmth and bacteria of environment the mono-, and dibasic phenols degrade easily to volatilizable phenols. Mono- and dibasic phenols are hazardous to environment (Kask et al 1990).

The degradation of lignin can be initiated only by white rot fungi, which abstract extracellular enzyme of ligninperoxidase, which is substantial for further oxidization of lignin (Ohuma et al 2001). Major part of the lignin is oxidized by catalyzing mangan peroxidase (MnP) and $\mathrm{H}_{2} \mathrm{O}_{2}$, which in addition to the white rot fungi is also produced by brown rot fungi (Collins et al 1997). Bacteria are important while degrading the lignin in conditions where the growth of fungi is restricted - in wood satiated with water, in the environment, where there is not enough air as well as high concentration of extractive components and in wood, which is treated by chemical preservatives as pentachlorophenol. (Tuomela 2002; by Blanchette 1995, Daniel, Nilsson 1998). In presence of enzymes the phenol groups are binded to quinone radicals, which during the further oxidization combine humus, $\mathrm{CO}_{2}$ and $\mathrm{H}_{2} \mathrm{O}$ (Gadd 2001; by Srinivasen et al 1995).

A general scheme of wood degradation is presented in Figure 1.

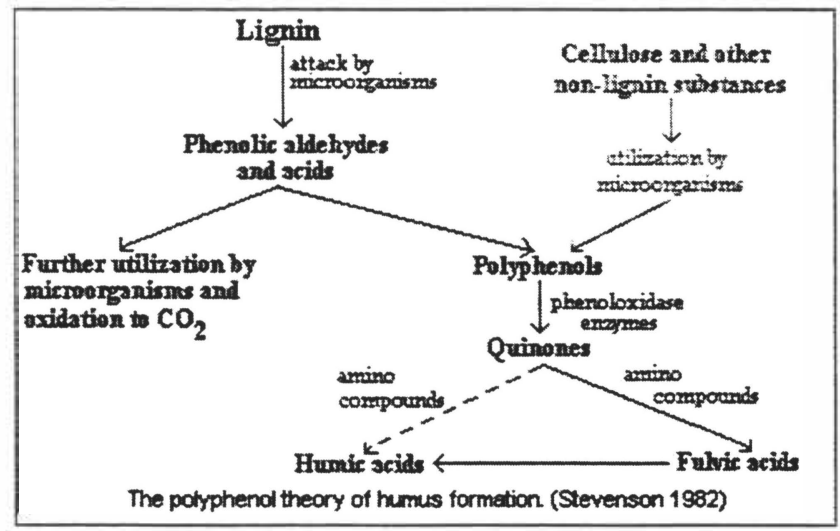

Figure 1. Formation of humus from polyphenols

\section{MATERIALS AND METHODS}

In the summer of the year 2002 the water samples were taken from trenches of waste wood dumping sites of Helme and Veriora. The results are shown in Tables 2 and 3. 
KALMAR ECO-TECH'03

Bioremediation and Leachate Treatment

KALMAR, SWEDEN, November 25-27, 2003

Helme and Veriora waste wood dumping sites are relatively similar by their composition. Both of them have also had mixed household waste, but recently only waste wood. Veriora dumping site is twice as old as Helme. In Table 1 there is the general data of the waste wood dumping sites of Helme and Veriora.

Table 1. General data about waste wood dumping sites of Helme and Veriora

\begin{tabular}{|l|c|c|}
\hline \multicolumn{1}{|c|}{ Indicator } & $\begin{array}{c}\text { Helme waste wood } \\
\text { dumping site }\end{array}$ & $\begin{array}{c}\text { Veriora waste wood } \\
\text { dumping site }\end{array}$ \\
\hline Age of dumping site, years & $15 \ldots .20$ & 45 \\
\hline Thickness of landfill, $\mathrm{m}$ & $0,5 \ldots 4,0$ & $\sim 5$ \\
\hline Expanse of dumping site, ha & $\sim 2,5$ & 3,07 \\
\hline
\end{tabular}

Table 2. Samples of Helme waste wood dumping site

\begin{tabular}{|l|c|c|}
\hline \multirow{2}{*}{$\begin{array}{c}\text { Component, } \\
\text { item }\end{array}$} & \multicolumn{2}{|c|}{ Sampling place } \\
\cline { 2 - 3 } & $\begin{array}{c}\text { sample 1, } \\
\text { trench by dumping site }\end{array}$ & $\begin{array}{c}\text { sample 2, } \\
\text { trench by dumping site }\end{array}$ \\
\hline $\mathrm{pH}$ & 7,01 & 7,08 \\
\hline $\mathrm{BOD} 7 \mathrm{mgO} / \mathrm{l}$ & 30 & 6,0 \\
\hline $\mathrm{CODMn} / \mathrm{mgO} / \mathrm{l}$ & 37 & 51 \\
\hline $\mathrm{N}$-tot $/ \mathrm{mg} / \mathrm{l}$ & 6,4 & 1,3 \\
\hline P-tot / mg/l & 0,090 & 0,074 \\
\hline Electric conduction $/ \mu \mathrm{S} / \mathrm{cm}$ & 1690 & 634 \\
\hline Volatalizing phenols $/ \mathrm{mg} / \mathrm{l}$ & $<0,005$ & $<0,005$ \\
\hline
\end{tabular}

Table 3. Samples of Veriora waste wood dumping site located in Veriora hamlet

\begin{tabular}{|l|l|l|}
\hline \multirow{2}{*}{$\begin{array}{l}\text { Component, } \\
\text { item }\end{array}$} & \multicolumn{2}{|l|}{ Sampling place } \\
\cline { 2 - 3 } & $\begin{array}{l}\text { Sample 1, groundwater } \\
\text { borehole in dry trench }\end{array}$ & $\begin{array}{l}\text { Sample 2, surface water } \\
\text { trench }\end{array}$ \\
\hline $\mathrm{pH}$ & 5,41 & 6,84 \\
\hline $\mathrm{BOD} / \mathrm{mgO} / \mathrm{l}$ & 12 & 14 \\
\hline $\mathrm{COD}_{\mathrm{Cr}_{\mathrm{r}} / \mathrm{mgO} / \mathrm{l}}$ & 2640 & 270 \\
\hline $\mathrm{N}-$ tot $/ \mathrm{mg} / \mathrm{l}$ & 14 & 4,0 \\
\hline $\mathrm{P}_{\text {-tot }} / \mathrm{mg} / \mathrm{l}$ & 3,5 & 0,34 \\
\hline $\mathrm{SO}_{4}{ }^{2 \cdot} / \mathrm{mg} / \mathrm{l}$ & $<4,0$ & $<4,0$ \\
\hline Electric conduction $/ \mu \mathrm{S} / \mathrm{cm}$ & 229 & 151 \\
\hline Monobasic phenols $/ \mu \mathrm{g} / \mathrm{l}$ & 17,3 & 17,1 \\
\hline Dibasic phenols $/ \mu \mathrm{g} / \mathrm{s}$ & 77,2 & 56,9 \\
\hline
\end{tabular}

The results were compared with the data of common waste dumping sites. It came out that the leachate of small waste wood dumping sites does not differ much from the one of common waste dumping sites. According to the valid legislative quota, in Veriora waste wood dumping site there was in excessive amount of $\mathrm{KHT}_{\mathrm{Cr}}$ instead of allowed $125 \mathrm{mg} / \mathrm{l}$. In one sample the concentration of $P$ (norm $2,0 \mathrm{mg} / \mathrm{l}$ ) was excessive as well. All the 
KALMAR ECO-TECH'03

Bioremediation and Leachate Treatment

KALMAR, SWEDEN, November 25-27, 2003

samples were taken during very dry period when the amount of water, permeated from the waste was inconsiderable. Therefore the available data is not sufficient to confirm that during the rainfall period the phenols don't leach into the soil in greater amounts than allowed.

For evaluating the environmental risks that coinside with wood storages the water samples taken from the waste wood storages and wood soak ponds were analysed.

In 1997 a wood industry situated in Võrumaa ordered to take a water sample from a biopond located in current direction of the emerging leachate from the wodge of wood bark. The concentration of monobasic phenols was $0,057 \mathrm{mg} / \mathrm{l}$ while in sample, taken from the same place in 2000 , the figure was $0,004 \mathrm{mg} / \mathrm{l}$ (Allowed quota is $0,1 \mathrm{mg} / \mathrm{l}$ in Estonia). The sample from the wodge of wood bark was taken in 1999. The results are shown in Table 4.

Table 4. Results of the water sample taken from the wodge of wood bark on the first of April in 1999.

\begin{tabular}{|l|c|c|}
\hline Komponent & Code & Result (mg/) \\
\hline Aeriform matter & PS C & 160 \\
\hline $\mathrm{BOD}_{7}$ & BOD/ NE & 1170 \\
\hline N-tot & NK NA & 7,0 \\
\hline P-tot & PTOT NS & 6,1 \\
\hline $\mathrm{SO}_{4}{ }^{2-}$ & SOa NTB & $<2,0$ \\
\hline Monobasic (volatilizing) phenols $^{2}$ & PHEN L & 1,1 \\
\hline
\end{tabular}

The concentrations compared to allowed quota, $\mathrm{BHT}_{7}$ exceed it 46,8 times, the amount of aeriform matter 4,6 times and phenols 11 times. The content of P-tot exceeds the norm about 3 times and the content of $\mathrm{N}$-tot was below the quota.

While emanating from biocleanser the concentration of $\mathrm{BHT}_{7}, \mathrm{~N}$-tot and P-tot was normalized but the amount of phenols $(0,006 \mathrm{mg} / \mathrm{l})$ still exceeded the quota. We can draw the conclusion that for degradation of phenols the bioponds are not effective due to the aggravation of the vital function of white rot fungi.

Based on data of ours, the concentration of monobasic phenols in wood soak ponds of Estonia is up to $3,23 \mathrm{mg} / \mathrm{l}$ and the same about dibasic phenols is $0,451 \mathrm{mg} / \mathrm{l}$. At the same time the content of aeriform matter is $1020 \mathrm{mg} / \mathrm{l}, \mathrm{BHT}_{7} 600 \mathrm{mg} / \mathrm{l}, \mathrm{N}$-tot $63 \mathrm{mg} / \mathrm{l}$ and P-tot $13 \mathrm{mg} / \mathrm{l}$.

During the years of 1987-1988, the research of the influence of organic filter materials to the quality of drain-water was conducted by RPUI 'Estonian Melioration Project'. The analysed components were $\mathrm{BHT}^{5}, \mathrm{NH}_{4}, \mathrm{NO}_{3}, \mathrm{PO}_{4}{ }^{2-}$ and P-tot. It appeared that utilization of filter materials influence in some degree the $\mathrm{BHT}_{5}$ of drain-water and the content of phenols, which were greater than in control system but at the same time did not exceed the allowed concentrations. The content of other components explored, compared to control systems, did not increase. But it was noticed that during the first year after having established the drainage, the concentration of phenols was about 2 times greater than in 
KALMAR ECO-TECH'03

Bioremediation and Leachate Treatment

KALMAR, SWEDEN, November 25-27, 2003

control fields. The content of phenols in drain-water inclined to degrease, but the amount of phenols increased also during the snow thawing in spring. It often appeared if the access of oxygen because of the estuary flood, snow or ice was restrained (Alekand et al 1991). The influence of organic filter materials disappeared within 3- 4 years. No toxic influence to surroundings was escertained (Alekand et al, 1989).

The amount of phenols becoming cleansed with rainfall water from wood was studied by Merle Suursaar, a student of Tallinn Technical University. The amount of BHT, KHT and phenols abstracted from the bark and sawdust of aspen and fir while irrigation was measured. Based on the results, the concentration of aforenamed components depending on the average amount of rainfall and the thickness of waste wood of Estonia was found out. It appeared that the amount of the phenols cleansed out by water from wood was quite great, reaching in the fill of aspen (thickness $0,5 \mathrm{~m}$ ) to $236,0 \mathrm{mg} / \mathrm{l}$. The conditions of this sample didn't afford the degradation and volatilization of the leached phenols the processes that take place in natural environment. It was not determined whether there are monophenols or phenol compounds.

The need to evaluate environmental hazards connected to the timber industry in the more complex way became clear during the study.

\section{CONCLUSIONS}

As a result of the research, it came out that up to the beginning of 1970ies the environmental problems in Sweden, Finland and Japan were caused not by natural wood but the wood treated with preservative - pentachlorophenol.

Based on data of earlier studies and the analysed water samples taken from soak ponds of plywood and veneer industries, waste wood dumping sites and the wodges of waste bark it was found out that the amount of leaching/ emerging phenols from untreated wood is rapidly degraded due to natural processes in the soil. In most cases the over-concentration of phenols caused by chemically untreated wood does not reach far away from the wood waste storages.

The leachate in the trench of waste wood dumping sites does not differ much from the leachate of common waste dumping sites.

Water is the factor that helps to accelerate the wood degradation and leaching of phenols, as a consequence, in case of rainfall, the amount of the phenols abstracted from the waste wood dumping site, can abruptly go up. Basically the degradation of phenols takes place in aerobic soil. In water and in badly aired solid the degradation of phenols is much slower.

Presumptive hazard to contaminate the environment may appear under following circumstances:

- in case if the great amounts of wood waste is stored too close to the body of water; 
KALMAR ECO-TECH'03

Bioremediation and Leachate Treatment

KALMAR, SWEDEN, November 25-27, 2003

- in case if the irrigation water of logs that has been in circulation for a long time is lead to nature.

\section{ACKNOWLEDGEMENTS}

The authors would like to thank company Kobras AS Ltd.

\section{REFERENCES}

[1] Alekand, K., Mander, Ü., Rebane, A., Salu, T., Timmusk, T., Uri, U., Alekand, P 1991. Aruanne. Kuivendussüsteemide projekteerimisaluste täiustamine (lep. nr. 1999)

[2] Alekand, K., Sepp, M., Mander, Ü., Laurand, J., Timmusk, T., Sepp, E., Rebane, A., Tambet, P., Kiiski, M., Uri, U., Kask, H. 1989. Kompleksaruanne. Maaparanduslike väliuurimuste ja projekteerimise aluste täiustamine (lep. nr. 199). Kuivendussüsteemide rekonstrueerimise ja sapropeelitootmise ehitustehnoloogiliste aluste täiustamine (lep. nr. 616). Kobras AS.

[3] Collins, P.J., Field, J.A., Teunissen, P., Dobson, A.D.W. 1997. Stabilisation on Lignin Peroxidases on White Rot Fungi by Tryptohan. - Applied and Environmental Microbiology 7: 2453-2548.

[4] Gadd, G.M. 2001. Fungi in Bioremidation. Cambridge Univeristy. Cambridge. Kättesaadav http://assets.cambridge.org/0521781191/sample/0521781191WS.PDF. 20.05.2003.

[5] Kask, H., Mugra, T., Otsa, E. 1990. Orgaaniliste drenaažimaterjalide mõju ümbritsevale keskkonnale. - Rmt-s: Päts, H. (koost) Maaparandus. Eesti Põllumajanduse Infokeskuse trükikoda, Tallinn. Lk. 3-11.

[6] Kirk,T. s.a. ENV 115: Environmental Microbiology. Kättesaadav http://intra.es.lancs.ac.uk:8080/es/env1 15/Lecturenotes115.pdf . 20.05.2003

[7] Kirk, T.K., Farell, R.L. 1987. Enzynatic "combution": the microbial degradation of lignin. - Ann Rev. Microbiol 41: 465-505.

[8] Land, V. 1985. Metsatööstuse tehnoloogia. Metoodiline käsitlus. Täht, Võru. 68 lk.

[9] Ohuma, M., Maeda, Y., Johijama, T. 2001. Lignin degradation and roles of white rot fungi: Study on an efficient symbiotic system - grawing termites and its application to bioreidation. - Pocused on Ecomolecular Science Reseach 12: 3942.

[10] Suursaar, M. 2003 Puidust vett reostvad ained. Bakalaureusetöö. Tallinna Tehnikaülikool.

[11] Tuomela, M. 2002. Academic dissertation in microbiology. Degradation of lignin and other ${ }^{14} \mathrm{C}$-labelled compounds in compost and soil with an emphasis on white-rot fungi. Department of Applied Chemistry and Microbiology of Helsinki. (http:/ ethesis. helsinki. fi/julkaisut/maa/skemi/vk/tuomela/degradat.pdf) 